\title{
Admission of new academicians to the National Academy of Medicine
}

\author{
Armando Mansilla-Olivares \\ Academia Nacional de Medicina, Ciudad de México, México
}

Learning is painful owing to its concentrated bitterness, but he who manages to like it thanks to his tenacity or to his infinite desire for self-improvement and service; or else, thanks to the skill of his teachers who guide and make him love that which in the beginning was rejected for being bitter, are precisely those who will fight the battle and will reach the proposed goal.

Marcus Fabius Quintilianus, Hispanic-Roman rhetorician and pedagogue, 50 AD.

Ladies and gentlemen, members of the National Academy of Medicine, distinguished Doctor José Narro Robles, exemplary academician, Federal Government Minister of Health, distinguished members of the head table, honorary academicians, former chairmen of the National Academy of Medicine, heads of department, special guests, personal guests, members of the Directive Board.

Throughout history and with gradual development of knowledge, driven by imperative needs faced from its beginnings and that had to be solved in a practical and expeditious way, since on that depended his subsistence, man went gradually organizing his knowledge and activities step by step in different fields, alternating accurate triumphs with overwhelming defeats, which brought him not only the ease of specialization but the command in the area he is responsible of. Among all of them, the most prominent, the leaders, those who have raised the banner by means of which they transformed, change and drive the development of humanity, have been the ones who managed to establish the difference between chaos and order by obtaining harmony, the correct arrangement, the right place, the agreement and respectful adjustment between things, between people, between different living beings; and that, in addition, have not lost the vision of a whole, even in the face of the highest ranges of specialization.

This, gentlemen, represents precisely the enormous wealth treasured by the National Academy of Medicine since its founding in 1864 . The extraordinary power the Academy has lies in the talent of each and every one of its members, in the constant and uninterrupted work they develop day by day, as well as in the strength of their knowledge and creativity, which they solidly express in their daily work, in those who surround them, with the simplicity and skill that characterizes the behavior of those who possess the mastery achieved by the command of knowledge and wisdom, resulting from the perseverance and experience acquired with an open mind, thirsting for knowledge and an indisputable scientific attitude, willing to invariably fight for the truth.

In this extraordinary venue, where the overflowing knowledge of minds and talent of all those who have given and give sustenance to it is breathed, we celebrate this day, on one hand, a group of academicians who, having been admitted in 2002, obtain -owing to their perseverance and prodigal dedication to medical science and to the Academy itself for the last 15 yearstheir full membership; and on the other, the renewal of the talent that surrounds us, with young minds from whom we expect to be truly worthy representatives of the National Academy of Medicine, and that with zeal, follow the example of those who have preceded us.

I am convinced that doctors and scientists who on this day are granted the enormous distinction of becoming part of the National Academy of Medicine as numerary members, appraise the extraordinary pride of what this means and will be worthy representatives of the medical-scientific and humanistic activity that from here emanates, raising the sense of belonging
Correspondence:

Armando Mansilla-Olivares

E-mail: armanolnc@gmail.com
Date of reception: 09-02-218

Date of acceptance: 15-03-2018

DOI://dx.doi.org/10.24875/GMM.M18000165
Gac Med Mex. 2018;154:353-354

Contents available at PubMed www.gacetamedicademexico.com 
and the serious and genuine intention to contribute, on behalf of the Academy, to the development and scientific evolution of contemporary medicine to the benefit of our population.

Today I also have the privilege of witnessing the appointment of two honorary academicians: one of them, a clinician and excellent Mexican scientist who has contributed with his deep knowledge, experience and talent, to strengthen and enlarge the pillars upon which this Academy rests, as well as to influence in a decisive way on scientific development in the international context, Dr. Julio Sotelo Morales; and another, doctor James Dewey Watson, Nobel Prize in Medicine, who will receive the investiture next November, in this same venue.

I want to emphasize that the National Academy of Medicine is not a power domain, but a crucible of wisdom, where extraordinarily brilliant minds of the most diverse areas of medicine, including philosophy and the most recondite of the molecular area and exact sciences, are melted.

That is why today I transmit and share with you with pride and enormous satisfaction, the extraordinary achievement reached last Friday, June 16, with the creation of the Council of National Academies, which is the product of the visionary attitude, tenacity and effort of doctors Jaime Parada Avila, Chairman of the Mexican Academy of Engineering, and Jaime Urrutia Fucugauchi, Chairman of the Mexican Academy of Sciences, immersed in an atmosphere of close friendship and solid links of union with the National Academy of Medicine, through its Chairman and with the support of each of one the Academies. The council Chair will be tripartite and its functions will be directed exclusively to the benefit of our society and the future of our country. With this, our Academy overwhelmingly and solidly strengthens the exercise of its vast experience and scientific influence.

Thank you very much for your attention. 